\title{
CAN A NON-MEMBER SPOUSE PROTECT HIS OR HER INTEREST IN THE MEMBER SPOUSE'S ACCRUED PENSION BENEFITS BEFORE DIVORCE?
}

\author{
MC Marumoagae \\ LLB LLM LLM (Dip in Insolvency Practice) \\ Senior Lecturer, University of the Witwatersrand
}

\section{SUMMARY}

A court hearing a divorce matter is empowered by relevant provisions of the Divorce Act to order that a portion of a member spouse's pension interest be assigned to his or her former spouse, which amount should be paid by the member's pension fund when it "accrues". In order to ensure that a non-member's spouse does not wait for a long period after the divorce to be paid his or her share of the member's pension interest, the clean break principle has been introduced to enable him or her to immediately claim his or her share of the member spouse's pension benefits on the date of divorce. However, when one spouse has been accorded his or her pension benefits during the subsistence of the marriage, there is no legislative provision which forces such a spouse to share such benefits with his or her non-member spouse. But the same spouse can claim against the pension interest of the other spouse when parties divorce. This note argues that there is a need for a legislative provision which would empower non-member spouses married in community of property to claim part of the pension benefits of their member spouses when they accrue during the subsistence of the marriage.

\section{$1 \quad$ INTRODUCTION}

Marriages in community of property result in a universal community of property, which entails that the parties thereto become tied or bound coowners in undivided and indivisible half-shares of all the assets and liabilities they have at the time of their marriage. ${ }^{1}$ There are various assets which

\footnotetext{
See Gugu v Zongwana [2014] 1 All SA 203 (ECM) par 16. See also Robinson "Matrimonial Property Regimes and Damages: The Far Reaches of the South African Constitution" 2007 3 PER 71, where it is submitted that a marriage in community of property is regarded "as a universal economic partnership of the spouses in which all their assets and liabilities are merged in a joint estate in which both spouses, irrespective of the value of their contributions hold equal shares". See also Marumoagae "The Beginning of the End Dissolution of Marriage under Accrual System" July 2015 De Rebus 38, where it is argued that "[u]nless excluded by a will, the general rule is that all the assets that the spouses had before the marriage, as well as assets they accumulate after entering into the marriage fall into the joint estate". It is possible for parties married in community of property to have separate estates, more particularly with regard to non-patrimonial assets.
} 
might constitute the joint estate of parties married in community of property thus being subject to division should parties divorce. At times, the pension benefits of both or either party may be the major financial consideration for division when the parties' divorce. As such, disputes regarding pension benefits have been subject to intense litigation in recent times. ${ }^{2}$ In most instances, only one party is an active member of a pension fund scheme at the time of divorce. As such, the relevant portion of his or her pension benefits becomes due for division immediately when the parties divorce. It is worth noting that what is divided at the time of divorce is not the member's spouse's pension benefits per se, but that part thereof which the member would have been entitled to receive had he or she withdrawn from the fund, referred to as the pension interest. ${ }^{3}$

Generally, pension benefits do not form part of the parties' joint estate when parties are married in community of property. ${ }^{4}$ However, the pension interest is deemed to be part of the member spouse's assets and would be subject to division when the parties divorce in terms of section 7(1) of the Divorce Act. ${ }^{5}$ The discussion regarding the division of pension benefits at the time of divorce has received judicial, legislative and academic attention over the years, and remains controversial to date. ${ }^{6}$ However, little or no attention has been paid to a situation where one of the spouses had received his or her pension benefits during the subsistence of the marriage, and did not share such benefit with his or her spouse, but when the parties divorce he or she claims his or her share on the other's spouse's pension interest. In this article, the author shall be arguing that there is a need for an express legislative provision which would allow non-member spouses to claim a portion of their spouses' pension benefits when they accrue during the subsistence of the marriage, even when the parties do not contemplate divorce. Despite its controversial nature, neither the legislature nor our courts have authoritatively dealt with this issue.

2 See Maharaj v Maharaj 2002 (2) SA 648 D\&CLD; Sempapalele v Sempapalele 2001 (2) SA 306; M L V J L Unreported case no 3981/2010 ZAFSHC 55 (25 April 2013); Kgopane $v$ Kgopane (1819/2011) [2012] ZANWHC 58 (16 August 2012); Kotze v Kotze [2013] JOL 30037 (WCC); and M v M (DIV 129/2012) [2014] ZANWHC 31 (30 October 2014).

3 Also see Davids $v$ Momentum Retirement Annuity Fund and Momentun Group Limited PFA/WE/35021/2009/LPM par 5.7. See also Marumoagae "A Non-Member Spouse's Entitlement to the Member's Pension Interest" 20146 PER 24882496.

4 See Kotze $v$ Kotze supra par 19; and see $M L v J L$ supra par 17.

570 of 1979.

6 See Marumoagae "Non-member's Entitlement to the Pension Interest of the Member's Pension Fund" 20146 PER 2488; and "A Critical Discussion of a Pension Interest as an Asset in the Joint Estate of Parties Married in Community of Property" 20141 Speculum Juris 55; Mothupi "Some Practical Effects of the Financial Services Laws General Amendment Act 2008 on Amending Section 37D(4) of the Pension Funds Act" 2012 SA Merc LJ 214; Nevondwe "The Law Regarding the Division of the Retirement Savings of a Retirement Fund Member on his or her Divorce with Specific Reference to Cockcroft v Mine Employees Pension Fund [2007] 3 BPLR 296 (PFA)" 2009 LDD 1-12. See also Old Mutual Life Assurance Co (SA) (Pty) Ltd v Swemmer 2004 (5) SA 373 (SCA); Eskom Pension and Provident Fund v Krugel 2012 (6) SA 143 (SCA); Kotze v Kotze supra; Ngewu v Post Office Retirement Fund 20134 BCLR 421 (CC); and Wiese v Government Employees Pension Fund 20126 BCLR 599 (CC). 


\section{PENSION BENEFITS AND THE ASSETS OF THE JOINT ESTATE}

Generally, marriages in South Africa are regarded as being in community of property, unless the spouses have concluded an antenuptual contract which indicates otherwise. ${ }^{7}$ The nature of marriage in community of property is that the spouses collectively own assets of the joint estate in equal undivided

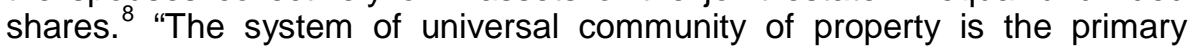
matrimonial property system in South Africa. During the subsistence of the marriage no asset can be physically divided and no rights pertaining to the joint estate can accrue exclusively to one of the spouse". 9 Section 1 of the

7 See Van Heerden, Cockrell, Keightley, Heaton, Clark Sinclair and Mosikitsana Boberg's Law of Persons and the Family 2ed (1999) 182. The Matrimonial Property Law in South Africa is primarily regulated by the Matrimonial Property Act 88 of 1984. In terms of this Act there are three possible marital regimes to choose from: marriage in Community of Property; Out of Community of Property, including the Accrual system; and Out of Community of Property, excluding the Accrual system. Thus, people are automatically married in Community of Property unless they had successfully concluded an Antenuptial Contract prior to their marriage, and had the contract attested before an attorney who is a Notary. When parties have signed an Antenuptual contract thereby choosing to marry Out of Community of Property, this will have the effect, that during the marriage each spouse retains control of his/her own property, builds up his/her own estate and each is responsible for his/her own debts. In terms of s 2 of the Act, every marriage Out of Community of Property in terms of an Antenuptial contract by which Community of Property and Community of Profit and Loss are excluded is automatically, subject to the accrual system, except in so far as that system is expressly excluded by the Antenuptial contract. In terms of Accrual System, the same principles which regulate the marriage Out of Community of Property marriage apply, but at the dissolution of the marriage, either because of death or divorce, the spouse whose estate shows a smaller accrual has a claim against the other spouse for an amount equal to half of the difference between the accrual of the respective estates of the spouses. See also Evans and Abrie "The Taxability of Insolvent Spouses who are Married in Community of Property" 20061 Stell LR 106. The authors correctly submit that "being married in community of property entails that the spouses become co-owners in undivided and indivisible half-shares of all the assets, and liabilities they have when marrying as well as of all the assets and liabilities they acquire during the marriage. The separate estates of husband and wife are therefore automatically merged into one joint estate for the duration of the marriage and the spouses administer the estate concurrently. The joint estate is liable for liabilities incurred by either of the spouses. When the marriage terminates, all liabilities are settled from the joint estate and the spouses then share equally in the balance of the joint estate". See also s 7(2) of the Recognition of Customary Marriage Act 120 of 1998 which provides that "[a] customary marriage entered into after the commencement of this Act in which a pouse is not a partner in any other existing customary marriage, is a marriage in community of property and of profit and loss between the spouses, unless such 55 consequences are specifically excluded by the spouses in an antenuptial contract which regulates the matrimonial property system of their marriage".

8 See Tomlin $v$ London and Lancashire Insurance Co Ltd 1962 (2) SA 30 (D) 33C-D; and W $v$ W 2011 (1) SA 545 (GNP) par 17. See also Evans and Abrie 20061 Stell LR 106, where it is argued that "being married in community of property entails that the spouses become coowners in undivided and indivisible half-shares of all the assets and liabilities they have when marrying and of all the assets and liabilities they acquire during the marriage. The separate estates of husband and wife are therefore automatically merged into one joint estate for the duration of the marriage, and the spouses administer the estate concurrently. The joint estate is liable for liabilities incurred by either of the spouses. When the marriage terminates, all liabilities are settled from the joint estate and the spouses then share equally in the balance of the joint estate".

9 Robinson 20073 PER 70 73. S 14 of the MPA specifically provides that "a wife in a marriage in community of property has the same powers with regard to the disposal of the 
Matrimonial Property $\mathrm{Act}^{10}$ provides that the phrase "joint estate" "means the joint estate of a husband and a wife married in community of property". This legislative definition does not really assist in explaining what the "joint estate" is, nor does it provide clarity of what it constitutes. However, a joint estate can loosely be referred to as the collection of individual patrimonial assets of the parties married in community of property with a view of merging them to create a single entity which parties can equally refer to and gauge their collective wealth and liabilities. It cannot be disputed that it is crucial for parties married in community of property to understand what constitutes their "joint estate and fully be aware of all the assets thereto so as to know their rights and how to protect them. This can be crucial more so when parties contemplate divorcing each other". ${ }^{11}$ In terms of section 14 of the Matrimonial Property $\mathrm{Act}^{12}$ both spouses in law have equal powers with regard to the management of their joint estate. ${ }^{13}$

When the spouses divorce, all the liabilities incurred by the spouses will be settled from the assets available within their joint estate. After the debts have been paid off, the balance will be distributed equally between the parties. However, if the parties were able to agree on a different method which the remaining assets should be divided between them, then they may conclude a written agreement and the division will be in accordance with such settlement agreement. ${ }^{14}$ In terms of marriage in community of property, it is irrelevant as to who brought what property into the joint estate, nor does it matter what the value of the estate of the individual spouse is, because from the date of the marriage one joint estate is established for the benefit of both spouses. However, Heaton correctly states that "the general rule that all assets of both spouses become part of the joint estate is subject to exceptions". ${ }^{15}$ Assets such as non-patrimonial benefits; those specifically excluded by virtue of an antenuptial contract; donations and inheritances

assets of the joint estate, the contracting of debts which lie against the joint estate, and the management of the joint estate as those which a husband in such a marriage had immediately before the commencement of this Act".

1088 of 1984 (hereinafter "MPA").

11 Marumoagae 20141 Speculum Juris 55.

1288 of 1984.

13 This section provides that "subject to the provisions of this Chapter, a wife in a marriage in community of property has the same powers with regard to the disposal of the assets of the joint estate, the contracting of debts which lie against the joint estate, and the management of the joint estate as those which a husband in such a marriage had immediately before the commencement of this Act".

14 However, as far as delictual damages (patrimonial damages) are concerned, it is a general principle of law that no person should be held responsible for another person's wrongdoings. If delictual damages during the duration of the marriage were paid from the joint estate, there must be an adjustment made in favour of the spouse who did not commit a delict when the estate is divided on divorce. Thus, in terms of $\mathrm{s} 19$ of the MPA "when a spouse is liable for the payment of damages, including damages for non-patrimonial loss, by reason of a delict committed by him or when a contribution is recoverable from a spouse under the Apportionment of Damages Act, 1956 (34 of 1956), such damages or contribution and any costs awarded against him are recoverable from the separate property, if any, of that spouse, and only in so far as he has no separate property, from the joint estate. Provided that in so far as such damages, contribution or costs have been recovered from the joint estate, an adjustment shall, upon the division of the joint estate, be effected in favour of the other spouse or his estate, as the case may be".

15 Heaton South African Family Law 3ed (2010) 66. 
which are expressly excluded from community of property by the testator/testatrix or donor; those acquired subject to a fideicomissum or usufruct as well as certain policies do not form part of the joint estate of parties married in community of property. ${ }^{16}$

It is ideal to note that pension benefits are not included in the list of assets which are excluded from the joint estate. As such, there might be those who are inclined to argue that pension benefits are assets in the joint estate. However, I submit that pension benefits of the member spouse who is married in community of property do not ordinarily and automatically form part of the joint estate established by his or her marital regime. This is due to the fact that, while such benefits are held by the fund and the event which triggers their release is yet to materialise, such benefits have not yet vested on the member. Hence, it is even impossible for all his or her creditors to claim against such benefits. ${ }^{17} \mathrm{~A}$ member spouse only has a right to claim such benefits when they accrue in terms of the rules of his or her fund. Indeed, a pension benefit that has not yet accrued to a person cannot be an asset in his or her estate, or in the joint estate for that matter. This is due to the fact that the right to claim the benefit vests only in the person when the benefit accrues to him or her, which might be as a result of retirement, resignation, dismissal and/ or retrenchment, as well as divorce. ${ }^{18}$ Further, even the non-member spouse cannot currently claim any portion of such benefits while the member is still active on the fund.

16 Ibid. See also Bath v Bath (952/12) [2014] ZASCA 14 (24 March 2014) par 9.

7 In terms of s 37A(1) of the Pension Funds Act 24 of 1956, "[s]ave to the extent permitted by this Act, the Income Tax Act, 1962 (58 of 1962), and the Maintenance Act, 1998, no benefit provided for in the rules of a registered fund (including an annuity purchased or to be purchased by the said fund from an insurer for a member), or right to such benefit, or right in respect of contributions made by or on behalf of a member, shall, notwithstanding anything to the contrary contained in the rules of such of a fund, be capable of being reduced, transferred or otherwise ceded, or of being pledged or hypothecated, or be able to be attached or subjected to any form of execution under a judgment or order of court of law, or to the extent of not more than three thousand rand per annum, be capable of being taken into account in a determination of a judgment debtor's financial position in terms of section 65 of the Magistrates' Court Act, 1944 (32 of 1944), and in the event of a member or beneficiary concerned attempting to transfer or otherwise cede, or to pledge or hypothecate such benefit or right, the fund concerned may withhold or suspend any benefit in pursuance of such contributions, or part thereof: provided that the fund may pay any such benefit or any benefit in pursuance of such contributions, or part thereof, to any one or more of the dependants of the member or beneficiary or to a guardian or trustee for the benefit of such dependent or dependants during such period as it may determine". See also Maharaj $v$ Maharaj supra 651B; and Kotze $v$ Kotze supra par 19, where Saldanha J held that "[w]here such benefit had not yet accrued it was not generally regarded as an asset in such pension holder's estate where the marriage was in community of property and moreover neither wat it regarded as an asset of the joint estate". See also $M L v J L$ supra par 17 , where Rampai $\mathrm{J}$ held that "[a]n individual's pension interest was never an asset in the joint estate of spouses married in community of property prior to the enactment of the aforesaid section 7 . Notwithstanding comments or views to the contrary, even after the enactment of section 7 , an individual's pension interest is still not an asset in a joint estate of spouses married in community of property. It is only an expectation of pension benefit yielded by a ripe pension interest which becomes an asset with real economic value".

18 Heaton "The Proprietary Consequences of Divorce" in Heaton (ed) The Law of Divorce and Dissolution of Life Partnerships in South Africa (2014) 74. 
The difference between two phrases: "pension interest" and "pension benefits" can be difficult to understand. For instance in $M L V J L^{19}$ it was held that "[w]hen a pension interest ripens, the administrator of the pension fund concerned determines the actual monetary value of a pension interest. Such value constitutes a pension benefit, which accrues from a ripe pension interest in favour or a member spouse". The court understood a pension benefit as being derived from a pension interest. ${ }^{20}$ However, in Eskom Pension and Provident Fund $v$ Krugel the court held that "[p]ension interest ... refers to the value of the interest which a member of a pension fund, on the date of his divorce, has in the pension benefit that will accrue to him as a member of such fund at a certain future date". ${ }^{21}$ This entails that a pension interest is derived from the pension fund. On the one hand, pension benefits can be understood as benefits which are due to the member of a pension fund as a result of the contributions which he or she has made to such fund when he or she exits the fund in accordance with its rules. On the other hand, pension interest relates to the member's spouse's notional withdrawal benefit that he or she would have been eligible to receive from his or her fund had he or she withdrawn his or her pension benefits from that fund on the date of divorce. Pension interest comes into play during divorce when a non-member spouse lays a claim to the member spouse's pension benefits, more particularly if the marriage is either in community of property or the accrual system is applicable to it. ${ }^{22}$

The South African Law Commission (June, 1999: as it was then) also recognised that "[a] pension interest is not a real asset that is open to division. It is the value that, on the date of divorce, is placed on the interest that a party to those proceedings has in the pension benefits that will accrue to him or her as a member of a pension fund or retirement annuity fund at a certain future date or event in accordance with the rules of the particular fund". ${ }^{23}$ It was held in Old Mutual Life Assurance Co (SA) Ltd v Swemmer that

"It would appear that, prior to 1 August 1989, the 'interest' which a spouse who was a member of a pension fund had in respect of pension benefits which had not yet accrued was generally not regarded as an asset in his or her estate or, where the marriage was in community of property, as an asset in the joint estate. This meant that, in determining the patrimonial benefits to which the parties to a divorce action were entitled, the 'pension expectations' of the member spouse were not taken into account."

supra par 18

20 See also $M L v J L$ supra par 19, where the court emphasised that "[a] pension benefit is accrually derivative from a pension interest".

21 Eskom Pension and Provident Fund v Krugel supra par 11.

22 S 1 of the Divorce Act 70 of 1979 defines the "phrase pension" interest as, "in relation to a party to a divorce action who - (a) is a member of a pension fund ... means the benefits to which that party as such a member would have been entitled in terms of the rules of that fund if his membership of the fund would have terminated on the date of the divorce on account of his resignation from office".

23 South African Law Commission Report on the Division of Pension Benefits on Divorce Project 41 (March 1995) and Report on Sharing of Pension Benefits Project 112 (June 1999).

24 Supra par 17. 
The South African Law Commission (as it was then) recognised that nonmember spouses were prejudiced by the fact that pension benefits did not form part of the joint estate, and could not be divided when the parties divorce, and that they could not be taken into account when the accrual is calculated. As a result the commission investigated the law in this regard and recommended that a mechanism be introduced in South African family law which would enable the non-member spouse to claim against his or her former spouse's pension benefits when the parties divorce. ${ }^{25}$ This led to the 1989 amendments to the Divorce Act which saw a phrase "pension interest" being coined to enable non-member former spouses to lay a claim to their former member spouse's pension benefits when they accrue to them. In order to ensure this, the commission saw it necessary to "deem" the pension interest as an asset in the estate of the member, and not to subject the pension benefits to the joint estate. In terms of section 7(7)(a) of the Divorce Act, when patrimonial benefits which divorcing spouses maybe entitled to are determined on the date of divorce, the pension interest of the member spouse shall be deemed to be part of such a member's assets. It is not entirely clear why a deeming provision was preferred, however, such provision remains instrumental in ensuring that the non-member spouse can now access a portion of his or her former member spouse's pension benefits. In Elesang v PPC Lime $L_{t d}{ }^{26}$ Olivier J held that "it is therefore only by means of this deeming provision (and the provisions of subsections (7) and (8) of section 7 of the Divorce Act) that a non-member spouse would be able to secure a part of a pension interest". ${ }^{27}$ As the law stands, and due to numerous amendments to both the Pension Funds $\mathrm{Act}^{28}$ and other legislation regulating certain public pension funds such as the Government Employees Pension Fund, divorce also triggers the withdrawal of pension interest in conformity with the clean break principle. ${ }^{29}$

It is submitted that the deeming provision is problematic in the sense it does not regard the pension interest to be an asset in the joint estate. This means that, due to the fact that the pension interest first needs to be deemed to be part of the estate of the member, it does not fall automatically within the joint estate. The deeming provision only comes into operation during divorce. In Sempapalele $v$ Sempapalele, ${ }^{30}$ the court held that deeming the pension interest to be an asset in the member's estate in terms of section 7(7)(a) of the Divorce Act, meant that the interest was not ordinarily part of the joint estate, but would be such for the purposes of the

25 South African Law Commission, Working Paper 4, Project 41, 1984: Investigation into the Possibility of Making Provisions for a Divorced Woman to Share in the Pension Benefit of her Former Husband. This commission is currently referred to as the South African Law Reform Commission.

262007 (6) SA 328 (NC).

27 Elesang $v$ PPC Lime Ltd supra par 14.

2824 of 1956.

29 A thorough discussion of the clean break principle is beyond the scope of this paper. See Marumoagae "Breaking up is Hard to Do, or is it? The Clean Break Principle Explained" October 2014 De Rebus 38.

30 Supra 311A 
divorce. ${ }^{31}$ This entails that, if there is no divorce, then pension benefits from which the pension interest is derived cannot lay open for division by the parties married in community of property.

It is submitted that it is time South Africa reviewed how pension benefits are viewed as far as marriages in community of property are concerned. It is concerning that pension benefits can only be legally dealt with by married parties when they divorce. It is unjustifiable that pension benefits should be viewed as pension interests only for the purposes of separation during divorce. In the sense that in order for the non-member spouse to claim against such benefits, an artificial mechanism should be created to deem such benefits to be part of the member spouse's assets for the purposes of divorce only. With a view that once they are part of the member spouse's assets, the non-member spouse would be able to lay a claim to them, without any legislative guidance of how they "move" from the personal estate of the member to the joint estate. It would be much easier if pension benefits themselves and not "pension interests" are viewed in the same light as other patrimonial benefits, and thus regarded as automatically falling within the joint estate by operation of law. This is because pension benefits are created from the financial benefits of the marriage. They are built by amounts which are deducted from the member's salary, which are patrimonial benefits of the marriage. Hence it cannot be that once the pension benefits have been built over a period of time, and the member has consciously married in community of property, once such benefits accrue then the law deems them to fall within the member's personal estate. As such, it is necessary to remove the deeming provision in order to allow the pension benefits to fall automatically within the joint estate of parties married in community of property. It has been argued that:

"Given the language adopted in section 7(7)(a)of the DA, which deems the pension interest to be an asset in the estate of the member spouse, I submit that this section is in effect converting the promise the pension fund made to its member into a realisable value capable of being divided. Now, due to the fact that the fund grants this particular promise only upon receipt of monthly premiums until the date of accrual, such premiums or part thereof are made directly from the salary of the member, which is in itself a patrimonial benefit of the marriage. If parties are married in community of property, unless there is an identifiable separate estate, ie where one of the parties received nonpatrimonial benefits during the course of the marriage which fell solely in his or her personal estate, such parties have only one joint estate and share in its profits and losses. Thus, in my view ... the pension interest should automatically be regarded as part of the joint estate by operation of law." 32

One of the major benefits of removing the deeming provision and treating pension benefits similar to other patrimonial benefits, would be that both spouses would have the same opportunity to lay a claim on each other's pension benefits as and when they accrue, more so during the subsistence of the marriage. The unfairness of a situation wherein one spouse during the subsistence of the marriage receives his or her pension benefits and does

31 See also Maharaj v Maharaj supra 651B, where it was held that prior to the introduction of s 7 into the divorce statute, one's pensions interest did not form part of the joint estate of spouses married in community of property.

32 Marumoagae 20146 PER 2509. 
not share with the other, but reserving his or her legal entitlement to claim the other spouse's pension interest should they divorce, would not arise. In that, the one from whose pension fund a claim would be laid during divorce cannot cry foul if he or she failed to claim from the other party when his or her pension benefits become due during the subsistence of the marriage. The law as it currently stands, it is possible for one spouse to receive his or her pension benefits during the marriage and utilise all such benefits for his or her personal purposes without sharing with the other. But when the parties divorce, notwithstanding, his or her action regarding his or her own pension benefits, he or she would be entitled to claim a portion of his or her spouse's pension interest when they divorce later on. This is because spouses are empowered by section $37 \mathrm{D}(4)(\mathrm{a})$ of the Pension Funds $\mathrm{Act}^{33}$ to claim from their member's spouses pension interest on the date of divorce, which is aimed at ensuring a clean break principle between such spouses.

\section{DISPUTES REGARDING PENSION BENEFITS WHICH ACCRUED BEFORE DIVORCE}

The law does not currently provide for non-member spouses who are married in community of property to claim part of their member spouses' pension benefits when such benefits accrues during the subsistence of the marriage, more particularly when parties are not contemplating divorce. Given the fact that non-member spouses married in community of property are entitled to claim pension interests of their spouses as at the date of divorce, it is submitted that there should be a legislative provision which empowers non-member spouses to also claim part of their spouses' pension benefits when they accrue during the subsistence of their marriages. Our courts will be confronted with instances where one of the parties had exited the fund and received his or her benefits before the divorce, but claims the pension benefits of his or her spouse which will accrue as a result of the parties divorce. In Elesang v PPC Lime Limited ${ }^{34}$ the parties were married in community of property and the husband was a member of a pension fund. He left his employment after the divorce action had been instituted by his wife. The wife approached the High Court and applied for an order that the fund should pay half of the member's pension interest into the trust account with her attorneys, pending finalisation of the divorce action. The Court looked at the definition of "pension interest" in section 1 of the Divorce Act, and held that the "pension interest" appears to apply only where one of the spouses is a member of a pension fund at the date of the divorce. The Court was of the view that because the husband was entitled to the benefits and had already left his employment, long before the date of the divorce, the formula based on benefits to which he "would have been entitled" in the event of resignation, could also strictly speaking no longer apply. ${ }^{35}$ As such, the fact that at the time of divorce the member spouse had already exited

\footnotetext{
24 of 1956.

34 Unreported case number 1076/2006 (15 December 2006).

35 Elesang v PPC Lime Limited (NC) unreported case number 1076/2006 (15 December 2006) par 11.
} 
the fund that meant that the non-member spouse as the law stands could not claim any part of such benefits.

In Eskom Pension and Provident Fund $v$ Krugel $^{36}$ the husband resigned from his employment in 1993 and elected to defer his pension benefits to his fund. He became a deferred pensioner during the subsistence of the marriage. However, the parties later divorced in or around 2001. The court was of the view that, because the husband had already resigned long before the divorce, his pension interest had already become payable to him. As such, he could not again be deemed to become entitled to a resignation benefit, and thus no longer had a pension interest for the purposes of section 7(7) and section 7(8) of the Divorce Act. ${ }^{37}$ In $M v M^{38}$ the parties were married to each other in community of property and the husband was a member of a pension fund. The wife instituted the divorce proceedings against the husband, who later retired and exited the fund before the divorce decree was granted. The wife then launched an urgent application seeking an order that her husband's fund should pay the portion of her husband's pension interest as per the settlement agreement which they had concluded, into her attorneys trust account pending the finalization of the divorce decree. ${ }^{39}$ The court concluded that the order applied for by the wife, when it was applied for, was not a competent order because at the time the husband had retired and the pension interest he had in the fund had ceased to exist. However, the court held that the wife was not without any remedy and could pursue her claim in terms of the settlement agreement. ${ }^{40}$

Perhaps the most important case concerning this paper is $M \vee M{ }^{41}$ However, in this case the most important facts relating to the theme of this paper were neither adequately formulated nor discussed in relation to the law. Nonetheless, this case provides a clear illustration of disputes which could arise when one party had received his or her pension benefits long before the date of divorce and did not share with the other, but when the parties divorce, then enforces his or her right to share on the other party's pension interest. In this case, the wife resigned in or around 2008 and her pension benefits were paid to her. When the parties divorced, the wife prayed for $50 \%$ of the husband's pension interest. The husband contended that the wife should forfeit her half share in his pension interest because she had liquidated her pension benefits in 2008 , and did not share such benefits with him. ${ }^{42}$ It appears from the judgment that this issue was neither properly canvassed and nor was any particular importance attached to it. There is no indication from the judgment that counsel from both sides argued the issue of the wife receiving her benefits long before the divorce. ${ }^{43}$ It is submitted

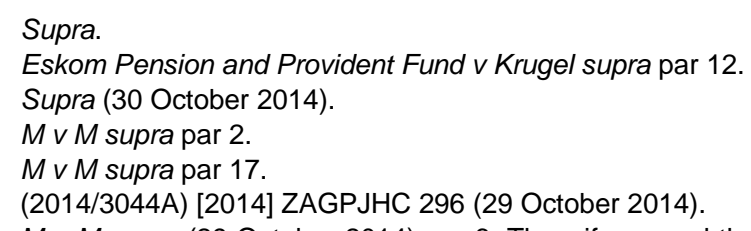
their children's education.

43 The court spent considerable time indicating how confused the magistrate was with sections $7(7), 7(8)$ (a)(i) and 9 of the Divorce Act, and how the magistrate's reasons are muddled. 
that the court ought to have requested both counsel to make submissions on this issue, because it appears to have been part of the defence, or rather broader argument of the husband, in justifying the need for his wife to be ordered to forfeit the pension interest. In my view, the court lost a golden opportunity to comment on the fairness or otherwise of spouses who receive their pension benefits and fail to share such benefits with their spouses before the date of divorce, but when they divorce they enforce their claims to share on their spouses' pension interest. The court set aside the order of the lower court and remitted it back to the magistrate to deal with the question of forfeiture in respect of the husband's pension interest.

\section{CLAIMING THE PENSION INTEREST DURING THE SUBSISTENCE OF THE MARRIAGE}

I am of the opinion that in the near future our courts will be called upon to adjudicate on the fairness of a spouse who is claiming a pension interest of his or her member spouse at the time of divorce, while he or she did not share his or her own pension benefits with such spouse which accrued way before the divorce. Spouses married in community of property should continue sharing their pension benefits when they are divorcing. However, when such benefits are not regarded as automatically falling within the joint estate, it would be fair to have a legislative provision which empowers nonmember spouses if the need arises, to claim their spouses' pension benefits during the subsistence of the marriage even when they are not divorcing. This will ensure that both parties, if they are members of pension funds, have fair access to each other's pension benefits, and if any of them does not claim when they are empowered to do so, it would be either out of choice or ignorance and not necessarily because the law does not provide for such option. As such, the legislature should endeavour to make provision for the sharing of pension benefits when they accrue during the subsistence of the marriage.

Should the proposal to do away with a deeming provision be rejected, alternatively, it may be ideal then to deem the "pension benefits", rather than the "pension interest" which is derived from the pension benefits as an asset in the joint estate, and not of the member's personal estate. If pension benefits are deemed as assets in the joint estate, then the procedure laid out in section 8(1) of the Matrimonial Property $\mathrm{Act}^{44}$ may be adopted to assist non-member spouses. In terms of this section any of the parties married out of community of property with the accrual system can apply to the High Court for the division of the growth of his or her spouse's estate which he or she has a right to share from when he or she feels that the other spouse is prejudicing his or her claim to such growth. ${ }^{45}$

4488 of 1984 (hereinafter "MPA").

45 See Marumoagae July 2015 De Rebus 38, where it is argued that "with section 8(1) of the MPA "spouses need not institute divorce proceedings in order to protect their share in the accrual of the estate of their spouses. If one spouse has acquired any financial benefit which grew his or her estate, that is, shares and subsequently negligently disposes of such shares with 'a view of prejudicing' the potential share the other spouse on his or her estate, then the spouse who is likely to be prejudiced may launch an application to the High Court for the division of the accrual in terms of section $8(1)$ without first having to institute divorce 
Section 8(1) of the MPA provides that:

"A court may on the application of a spouse whose marriage is subject to the accrual system and who satisfies the court that his right to share in the accrual of the estate of the other spouse at the dissolution of the marriage is being or will probably be seriously prejudiced by the conduct or proposed conduct of the other spouse, and that other persons will not be prejudiced thereby, order the immediate division of the accrual concerned in accordance with the provisions of this Chapter or on such other basis as the court may deem just."

This would enable non-member spouses to approach the court for relief regarding division of assets while the marriage is still on, especially when the parties do not contemplate divorce. With this provision, spouses need not institute divorce proceedings in order to protect their share in the accrual of the estate of their spouses. If one spouse has acquired any financial benefit which grew his or her estate, that is, shares and subsequently negligently disposes of such shares with "a view of prejudicing" the potential share the other spouse on his or her estate, then the spouse who is likely to be prejudiced may launch an application to the High Court for the division of the accrual in terms of section 8(1) without first having to institute divorce proceedings. As such, in the same way as spouses married subject to the accrual system can approach the court for the division, it would be ideal to have a legislative provision empowering non-member spouses also to apply to court for the division of the accrued pension benefits during the subsistence of the marriage. I therefore recommend that the Divorce Act should be amended by the introduction of a specific provision which will empower non-member spouses to be able to claim a percentage of their member spouse's pension benefits when such benefits are paid to member spouses during the subsistence of the marriage.

It is worth noting that if my proposals regarding the amendments to the Divorce Act relating to the pension benefits being part of the joint estate and removing deeming provisions when parties are married in community of property, are adhered to, there might not be a need to have regard to section $8(1)$ of the MPA. This is because section 20(1) of the MPA already provides the court with the power to order division of the joint estate on application by either spouse who believes that his or her interest in the joint estate would be seriously prejudiced by the conduct or proposed conduct of the other spouse. Under such circumstances, the court may order immediate division of the joint estate despite the fact that the parties have not instituted divorce proceedings. However, section 20(1) of the MPA will not be effective if the deeming provisions are still applicable. This is, because should any spouse make an application in terms of this provision during the subsistence of the marriage, while the court may divide the joint estate, the pension benefits would not be subject to such division, because in terms of section $7(7)(a)$ of

proceedings". See also Heaton "Mental and Physical Disability: Prodigality" in Van Heerden (ed) Boberg's Law of Persons and the Family 2ed (1999) 151, where it is argued that "in a marriage out of community of property and of profit and loss and with the accrual system, the court has a similar power to order immediate division of the accrual if the applicant satisfies it that his or her right to share in the accrual of the estate of the other spouse at the dissolution of the marriage is being or will probably be seriously prejudiced by the conduct or proposed conduct of the other spouse, and that no other person will be prejudiced by the order". 
the Divorce Act the pension interest can only be deemed to be part of the member's estate on the date of divorce.

\section{CONCLUSION}

The discussion regarding the status of pension benefits with regard to the joint estate is far from over in South Africa. Currently, only the pension interest is deemed to be part of the member's spouse's assets in terms of section 7(7) of the Divorce Act. In terms of section 37D(4) of the PFA, for the purpose of section 7(8)(a) of the Divorce Act, the portion of the "pension interest" assigned to the non-member spouse in terms of a decree of divorce is deemed to "accrue" to the member of the fund on the date the decree of divorce is granted. It was shown in this article that the law caters only for the division of the pension interest when the parties are divorcing. Further that the law does not provide relief for non-member spouses who may wish to claim part of their spouses' pension benefits during the subsistence of the marriage. As such, this paper recommended that there is a need to make legislative provision for spouses married in community of property to be able to claim part of their member spouses' pension benefits when they accrue during the subsistence of the marriage. 